REPORT

\title{
Alefacept for psoriasis and psoriatic arthritis
}

\section{A B Gottlieb}

Alefacept is a bioengineered fusion protein of soluble lymphocyte function antigen (LFA-3) with Fc fragments of $\operatorname{lgG1}$. It is marketed in many countries for the treatment of moderate to severe psoriasis. This paper reviews the data supporting the use of alefacept in psoriasis and psoriatic arthritis.

\begin{abstract}
A lefacept is a bioengineered fusion protein of soluble Lymphocyte Function Antigen (LFA-3) ${ }^{1}$ with Fc fragments of IgGl. It is marketed in the USA, Australia, Canada, Argentina, Switzerland, Kuwait, and Israel as monotherapy for the treatment of moderate to severe psoriasis vulgaris. It binds to CD2 on memory effector T cells and blocks the interaction between LFA-3 on antigen presenting cells (APCs) and CD2 on the activated T cells. It is thought to deplete CD2+T cells by binding to natural killer (NK) cells via its FC region. ${ }^{2}$ Although its mechanism of action in vivo is incompletely understood, it is thought to improve psoriasis by inducing apoptosis of memory $\mathrm{T}$ cells, inhibiting costimulation of $\mathrm{T}$ cells, decreasing inflammatory gene expression by multiple cell types and decreasing infiltration of $\mathrm{T}$ cells and dendritic cells (DCs) in psoriatic plaques. $^{2-4}$ Over 12000 patients with psoriasis have been treated with alefacept since its approval in 2003. This paper reviews the available data for the treatment of psoriasis and introduces the results of the recent phase 2 study of alefacept in combination with methotrexate for the treatment of psoriatic arthritis.
\end{abstract}

\section{CLINICAL TRIALS OF ALEFACEPT IN PSORIASIS}

In a randomised, double blind, placebo controlled phase 3 study, patients with moderate to severe psoriasis vulgaris were treated with alefacept $15 \mathrm{mg}$ monotherapy or placebo intramuscularly (IM) on a weekly basis for 12 weeks. ${ }^{5}$ The primary endpoint was predetermined at two weeks following the twelfth injection of alefacept. Patients were then observed for 12 weeks on no therapy except for emollients. At the primary endpoint, $21 \%$ of patients achieved at least a $75 \%$ improvement in psoriasis disease activity as measured by the Psoriasis Area and Severity Index (PASI 75). ${ }^{6}$ However, during the 12 week follow up period, an additional $7 \%$ of patients achieved PASI75. A second 12 week course of alefacept resulted in an additional $10 \%$ of patients achieving PASI 75 with an overall response of $43 \%$ of patients reaching PASI 75. ${ }^{7}$ Approximately half of the patients reached PASI 50 at any time during the first course, and after a second course, $69 \%$ reached PASI $50 .{ }^{7}$ Unfortunately, the extent of circulating CD4+ T cell depletion did not predict a patient's response during treatment or follow up. ${ }^{3}$ Alefacept is a remittive treatment, allowing patients time away from therapy. ${ }^{8-11}$ In those patients achieving a PASI 75 or better at any time during the first course of therapy, the time until loss of a PASI 50 response was a median of 209 days. ${ }^{8}$ Treatment with multiple courses of alefacept showed increasing efficacy and there was no evidence of tachyphylaxis during multiple courses of treatment ${ }^{12}$

\section{Monitoring drug safety}

The safety profile of alefacept is encouraging, with some patients having received up to nine courses of alefacept in phase 2 and 3 clinical trials and their extensions. There was no increase in adverse events in patients treated with alefacept compared with placebo. ${ }^{5}$ Consistent with memory effector $\mathrm{T}$ cell depletion as a mechanism of action was the requirement for weekly monitoring of circulating $\mathrm{CD} 4+\mathrm{T}$ cell counts during the 12 dosing weeks in phase 3 clinical trials. Patients did not start taking alefacept if their CD4+ $\mathrm{T}$ cell count was $<400$; dosing was withheld when the CD4+ T cell count fell below 250. However, patients whose CD4+ T cell counts fell below 250 in clinical trials did not experience an increased incidence of infection. ${ }^{11}$ There was no increased incidence of malignancies, including cutaneous cancers, in clinical trials comparing alefacept with placebo. ${ }^{511} 13$ Although larger numbers of patients are needed, repeated administration of alefacept, with some patients having received up to nine clinical trial courses of alefacept, showed a favourable safety profile, with no increase in malignancies or serious infections over repeat courses. ${ }^{14}$

Data from nine multicentre, randomised, phase 2 and 3 clinical studies (and their extensions) were integrated to evaluate the safety and efficacy of alefacept in three special, potentially higher risk, patient populations-elderly, obese, and diabetic patients. ${ }^{15}$ Elderly patients were those who were $\geqslant 65$ years of age at the time of the first alefacept dose $(\mathrm{n}=99)$. Obese patients had a body mass index $\geqslant 30 \mathrm{~kg} / \mathrm{m}^{2}$ $(\mathrm{n}=652)$. Diabetic patients were identified as having a history of diabetes $(n=122)$. The patients received up to four courses of alefacept. Similar proportions of patients achieved PASI 75 in all three subgroups as did the total clinical trial population. There were no differences in safety observed in any of the three subgroups compared with the total clinical trial population. As clinical experience with alefacept accumulates, future analyses involving larger numbers of elderly, obese, and diabetic patients will help to confirm these results.

Alefacept demonstrated clinical improvement in patients with special forms of psoriasis. Two patients with palmoplantar psoriasis were successfully treated with a course of alefacept monotherapy ${ }^{16}$ in addition to a patient with palmoplantar pustular psoriasis. ${ }^{17}$ In exploratory studies, clinically significant improvement in nail psoriasis, which is often difficult to treat, has been noted..$^{18} 19$

To evaluate the effect of alefacept on immune function, $\mathrm{T}$ cell dependent humoral responses to a neoantigen ( $\phi$ X174) and recall antigen (tetanus toxoid) were assessed. ${ }^{20}$ Psoriatic patients were randomised to alefacept ( $7.5 \mathrm{mg}$ intravenously weekly for 12 weeks) or control group. The alefacept group received $\phi$ X174 immunisations at weeks 6, 12, 20, and 26 and tetanus toxoid at week 21 ; controls received $\phi$ X174 at weeks 6 and 12 , and tetanus at week 10 . Mean anti- $\phi$ X174 titres were comparable in the two groups. There was no difference in the 
percentage of responders (anti- $\phi$ X174 IgG $\geqslant 30 \%$ of the total anti- $\phi$ X174) between the alefacept and control groups $(86 \%$ and $82 \%$, respectively; $p=0.73$ ). The percentage of patients whose anti-tetanus toxoid titre increased $\geqslant 2$ times the baseline was also similar (alefacept, 89\%; control 91\%). Thus, a single 12 week course of alefacept did not impair primary or secondary antibody responses to a neoantigen (despite the fact that immunisation occurred during the trough of CD4+ T cell counts) or memory responses to a recall antigen. Alefacept treatment appears to maintain a humoral immune response to vaccination, and presumably, infection.

In the USA, alefacept is indicated in patients with moderate to severe psoriasis vulgaris who are candidates for systemic or phototherapy. Patients must have circulating CD4 count of at least 400 prior to starting alefacept. Currently, CD4 T cell counts must be monitored weekly and alefacept doses should be held if the CD4 count falls below 250. Patients receive 12 , weekly doses of alefacept $15 \mathrm{mg}$ IM followed by a 12 week observation period. If their psoriasis flares during this observation period, patients may be offered a second 12 week course of alefacept. There are patients who have received up to 10 courses of alefacept in clinical trials or in community practice, but the numbers of these patients are still limited..$^{71}$ Studies are under way to determine if less frequent monitoring of circulating CD4+ T cells-both every two weeks and monthly-is equivalent to the current weekly monitoring requirement. To date, there have been no safety related issues surrounding reduced monitoring or in patients with CD4+ counts that went below 250 during treatment. ${ }^{21}$ In addition, long term efficacy and safety databases have been established for alefacept as it is used by community and academic dermatologists. In the 12000 patients treated to date, no new safety liabilities have been reported.

\section{COMBINATION THERAPIES}

Although the package insert for alefacept cautions against combining with other immunosuppressive drugs, in clinical practice it is necessary to at least overlap alefacept with ultraviolet B (UVB) or traditional systemic agents (methotrexate, ciclosporin, acitretin) due to the delay in the onset of action of alefacept. Studies of small series of patients, tapered off either methotrexate or ciclosporin over a few months while initiating a single 12 week course of alefacept therapy, proved to be successful for most patients. ${ }^{22-26}$ There was no increase in toxicity of methotrexate, ciclosporin, or alefacept during the time period in which the drugs were overlapped. Narrowband and broadband UVB therapy have been combined with alefacept in single centre studies without an increase in skin cancer or other adverse events. It is difficult to assess if the combination of UVB phototherapy with alefacept is more efficacious than UVB alone as there was no UVB monotherapy cohort in either series of patients. ${ }^{27}$ There are no reported data on the combination of alefacept with psoralen plus UVA (PUVA).

Demonstration of clinical efficacy in psoriatic arthritis and decreases in synovial $\mathrm{T}$ cell and macrophage infiltration were demonstrated in an open study of a small series of psoriatic arthritis patients treated with alefacept $7.5 \mathrm{mg}$ intravenously dosed once weekly for 12 weeks. ${ }^{28}$ Most recently, a phase 2 study of alefacept in combination with methotrexate for psoriatic arthritis was presented. In this study, psoriatic arthritis patients with three or more tender and swollen joints and who were on stable doses (10-25 mg/week) of methotrexate for at least three months, were randomised to receive either placebo $(n=62)$ or alefacept $15 \mathrm{mg}$ IM $(\mathrm{n}=123)$ per week for 12 weeks. ${ }^{29}$ Responders were defined as those patients achieving at least $20 \%$ improvement (American College of Rheumatology (ACR 20)) in clinical arthritis activity. The primary endpoint was at week 24 , three months after the last dose of alefacept. At baseline the mean methotrexate dose was approximately $14 \mathrm{mg} /$ week. Baseline weight, duration of psoriatic arthritis, number of tender and swollen joints, pain score, quality of life score (Heath Assessment Questionnaire, disability index (HAQ-DI)), physician and patient global assessment scores, and erythrocyte sedimentation rates were comparable in both cohorts. The baseline C-reactive protein was slightly higher in the placebo (16.7) as compared with the alefacept treated (13.8) cohort. At the primary endpoint (six months), 54\% of the alefacept versus only $23 \%$ of the placebo cohort achieved an ACR 20 . There were no increased numbers of adverse events in the alefacept treated cohort compared with the placebo cohort. Alefacept in combination with methotrexate was evaluated in a small pilot study in rheumatoid arthritis, with a significant proportion of patients achieving ACR 20 compared with placebo. ${ }^{30}$

\section{CONCLUDING REMARKS}

Unanswered questions remain regarding the mechanism of action of alefacept in psoriasis:

- If depletion of memory $\mathrm{T}$ cell via apoptosis is a predominant mechanism of action why is the onset of action of alefacept delayed? ${ }^{2}$

- Why is it that depletion of circulating CD4+ T cells is not predictive of clinical response? ${ }^{1113}$

- If memory $\mathrm{T}$ cells are pathogenic, why do only a third of patients achieve PASI 75?

- If CD4 memory T cells are depleted by alefacept why is the switch from IgM to IgG in primary immune responses to vaccination intact?

Opportunities to increase the utility of alefacept include:

- identifying before initiation of treatment, those psoriasis patients who are likely to have a good clinical response to alefacept

- accumulating more efficacy and safety data on the use of alefacept in combination with UVB and systemic psoriasis therapies since alefacept's onset of action delayed

- evaluating other dosing strategies with alefacept

- extending the use of alefacept to other T cell mediated diseases.

Competing interests: A B Gottlieb is a consultant, speaker, and investigator for Biogen Idec, Inc.

Correspondence to: A B Gottlieb, Clinical Research Center, UMDNJRobert Wood Johnson Medical School, 51 French St., New Brunswick, NJ 08901-0019, USA; alice.gottlieb@umdnj.edu

\section{REFERENCES}

1 Springer TA, Dustin ML, Kishimoto TK, Marlin SD. The lymphocyte functionassociated LFA-1, CD2, and LFA-2 molecules: cell adhesion receptors of the immune system. Annu Rev Immunol 1987;5:223-52.

2 Cooper JC, Morgan G, Harding S, Subramanyam M, Majeau GR, Moulder K et al. Alefacept selectively promotes NK cell-mediated deletion of CD45RO+ human T cells. Eur J Immunol 2003;33:666-75.

3 Chamian F, Lowes MA, Lin S-L, Lee E, Kijuchi T, Gilleaudeau P, et al. Alefacept reduces infiltrating $T$ cells, activated dendritic cells and inflammatory genes in psoriasis vulgaris. Proc Natl Acad Sci U S A 2005; 102:20675-80.

4 daSilva AJ, Brickelmaier M, Majeau GR, Li Z, Su L, Hsu YM, et al. Alefacept, an immunomodulatory recombinant LFA-3/lgG1 fusion protein, induces CD16 signaling and CD2/CD16-dependent apoptosis of CD2+ cells. $J$ Immunol 2002; 168:4462-71.

5 Lebwohl M, Christophers E, Langley R, Ortonne JP, Roberts J, Griffiths CE; Alefacept Clinical Study Group. An international, randomized, double-blind, placebo-controlled phase 3 trial of intramuscular alefacept in patients with chronic plaque psoriasis. Arch Dermatol 2003;139:719-27.

6 Frederiksson T, Pettersson U. Severe psoriasis oral therapy with a new retinoid. Dermatologica 1978;157:238-44. 
7 Langley RD, Christophers E, Lebwohl M. Efficacy and safety of multiple courses of intramuscular alefacept in patients with chronic plaque psoriasis. J Invest Dermatol 2002;119:344.

8 Gordon KB, Langley RG. Remittive effects of intramuscular alefacept in psoriasis. J Drugs Dermatol 2003;2:624-28.

9 Gottlieb AB. Product development for psoriasis: clinical challenges and opportunities. In: Roenigk H, Maibach H, eds. Psoriasis. New York: Marcel Dekker, 1997.

10 Gottlieb AB. Psoriasis. Dis Manag Clin Outcomes 1998;1:195-202.

11 Krueger GG, Patt KA, Strough DB, Loven KH, Gulliver WP, Ellis CN, Afefacept Clinical Study Group. A randomized, double-blind, placebo-controlled phase III study evaluating efficacy and tolerability of 2 courses of alefacept in patients with chronic plaque psoriasis. J Am Acad Dermatol 2002;47:821-33.

12 Menter A, Baker D, Farber H, Lebwohl M. Long-term use of alefacept: efficacy and off-treatment responses in patients who have received multiple courses of therapy [abstract]. J Am Acad Dermatol 2005;52:P2-Abstract P7.

13 Ellis CN, Krueger GG; Group ACS. Treatment of chronic plaque psoriasis by selective targeting of memory effector T lymphocytes. N Engl J Med 2001;345:248-55.

14 Goffe B, Papp K, Gratton D, Krueger GG. Long-term safety of alefacept in patients who have received up to nine courses of therapy [abstract]. J Am Acad Dermatol 2005;52:P190-Abstract P, 2773.

15 Gottlieb AB. Safety and efficacy of alefacept in patients with older than 60 years of age and in patients with diabetes [abstract]. J Am Acad Dermatol 2005;52:P175-Abstract P, 2716

16 Myers W, Christiansen L, Gottlieb AB. Treatment of palmoplantar psoriasis with intramuscular alefacept. J Am Acad Dermatol (in press).

17 Yeung-Yue KA, Aronson PJ, Murakawa. Clinical improvement of palmoplantar pustular psoriasis with alefacept. J Am Acad Dermatol 2005; 52:179

18 Cassetty CT, Alexis AF, Shupack JL, Strober BE. Alefacept in the treatment of psoriatic nail disease: a small case series. J Am Acad Dermatol 2005;52:1101-2.

19 Strober BE, Cassetty C. Alefacept in the treatment of psoriatic nail disease [abstract]. J Am Acad Dermatol 2002;50:151.
20 Gottlieb AB, Casale TB, Frankel E, Goffe B, Lowe N, Ochs HD, et al. CD4+ Tcell-directed antibody responses are maintained in patients with psoriasis receiving alefacept: Results of a randomized study. J Am Acad Dermatol 2003;49:816-25.

21 Ticho B, Bozic C, Cather JC. A simple algorithm for reduced lymphocyte monitoring with alefacept therapy. J Am Acad Dermatol 2005;52:174.

22 Menter A, Abramovits W, Cather JC. Alefacept in combination with tapering doses of methotrexate in patients with psoriasis. Poster presented at the 62nd annual meeting of the American Academy of Dermatology, Washington DC, 6-11 February, 2004

23 Lozano AM, Van Saders C, Gottlieb AB. A safe and effective strategy for transitioning patients with psoriasis from cyclosporine to alefacept therapy. J Am Acad Dermatol 2005;52:174

24 Magliocco MA, Lozano A, Van Saders C, Gottlieb AB. A safe and effective strategy for transitioning patients with psoriasis from cyclosporine to alefacept therapy [abstract]. J Am Acad Dermatol 2005;52:P174-Abstract P, 2710.

25 Cather JC, Mann J, Abramovits W, Menter A. The safety of alefacept used in combination with conventional systemic psoriasis therapies [abstract]. J Am Acad Dermatol 2005;52:P199-Abstract P, 2808

26 Cather JC, Meier A, Young M, Menter A. Transitioning patients with psoriasis from conventional systemic psoriasis therapies to alefacept [abstract]. J Am Acad Dermatol 2005;52:P200-Abstract P, 2813

27 Ortonne JP, Khemis A, Koo JYM, Choi J. An open-label study of alefacept plus ultraviolet $B$ light as combination therapy for chronic plaque psoriasis. J Eur Acad Dermatol Venereol (in press)

28 Kraan MC, van Kuijk A, Dinant H, Goedkoop AY, Smeets TJ, de Rie MA, et al. Alefacept treatment in psoriatic arthritis: reduction of the effector $T$ cell population in peripheral blood and synovial tissue is associated with improvement of clinical signs of arthritis. Arthritis Rheum 2002;46:2776-84.

29 Lebwohl M, Menter A. The treatment of active psoriatic arthritis with alefacept in combination with methotrexate: a randomized, double-blind, placebocontrolled study. Presented at the 29th Hawaii Dermatology Seminar, March 18-24, 2005, Maui, Hawaii.

30 Schneider M, Stahl H-D, Podrebarac T, Braun J. Tolerability and safety of combination methotrexate and alefacept in rheumatoid arthritis: results of a pilot study. Arthritis Rheum 2004;12:S654. 